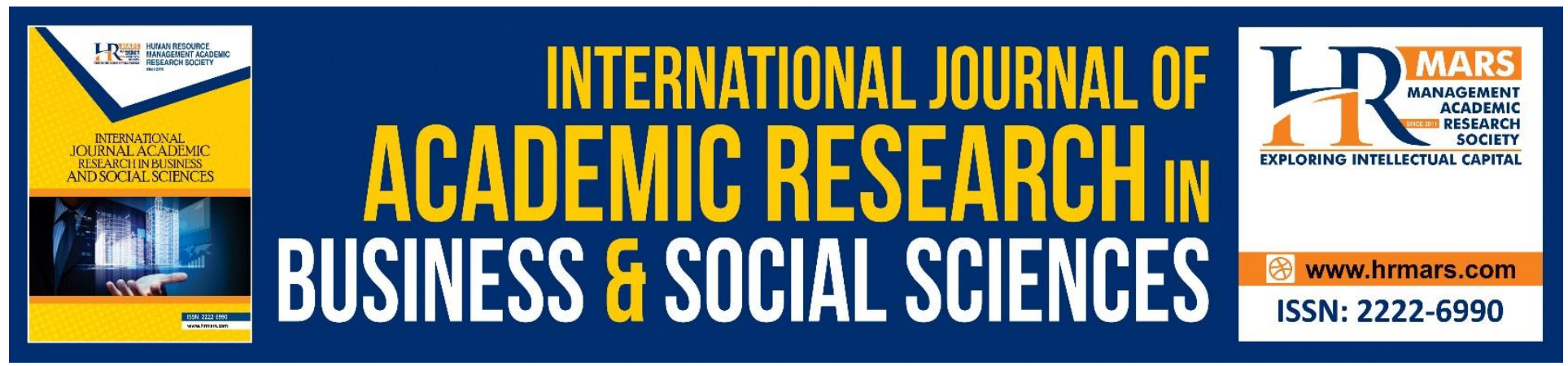

\title{
Hear Me Out! Digital Storytelling to Enhance Speaking Skills
}

\author{
Precintha Rubini A/P P. James, Kung Lian Yong, Melor Md. Yunus
}

To Link this Article: http://dx.doi.org/10.6007/IJARBSS/v9-i2/5533

DOI: $\quad 10.6007 /$ IJARBSS/v9-i2/5533

Received: 04 Jan 2019, Revised: 19 Feb 2019, Accepted: 27 Feb 2019

Published Online: 09 March 2019

In-Text Citation: (James, Yong, \& Yunus, 2019)

To Cite this Article: James, P. R. A. P., Yong, K. L., \& Yunus, M. M. (2019). Hear Me Out! Digital Storytelling to Enhance Speaking Skills. International Journal of Academic Research in Business and Social Sciences, 9(2), 190-202.

\section{Copyright: (C) 2019 The Author(s)}

Published by Human Resource Management Academic Research Society (www.hrmars.com)

This article is published under the Creative Commons Attribution (CC BY 4.0) license. Anyone may reproduce, distribute, translate and create derivative works of this article (for both commercial and non-commercial purposes), subject to full attribution to the original publication and authors. The full terms of this license may be seen

at: http://creativecommons.org/licences/by/4.0/legalcode

Vol. 9, No. 2, 2019, Pg. 190 - 202

http://hrmars.com/index.php/pages/detail/IJARBSS

JOURNAL HOMEPAGE

Full Terms \& Conditions of access and use can be found at http://hrmars.com/index.php/pages/detail/publication-ethics 


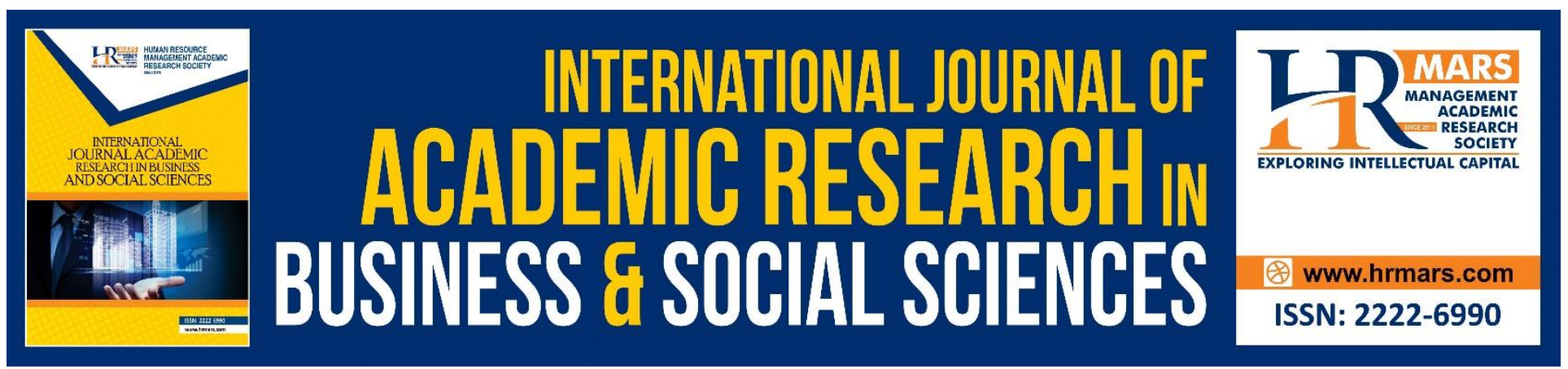

\title{
Hear Me Out! Digital Storytelling to Enhance Speaking Skills
}

\author{
Precintha Rubini A/P P. James \\ SMK Seri Bentong, Malaysia \\ Email: preciz16@yahoo.com \\ Kung Lian Yong \\ SMK Raja Ali, Malaysia \\ Email: kunglianyong@gmail.com \\ Melor Md. Yunus \\ Universiti Kebangsaan Malaysia, Malaysia \\ Email:melor@ukm.edu.my
}

\begin{abstract}
In public schools in Malaysia, English is taught for a good 11 years. Nevertheless, it is alarming that although students are able to craft well-written essays, not all of them are able to speak English fluently upon completing secondary school. There is an imbalance of the production skills. Therefore, this study aims to investigate the use of digital storytelling in enhancing students' speaking skills in English and the perceptions of the students with regards to the use of digital storytelling to improve their speaking skills. The study was carried out with 20 Form 4 students studying in a suburban school in Pahang, Malaysia. The main instrument used in this study is the School Based Oral Assessment (SBOA) form which was used for the pre-test and posttest. Their language proficiency was rated as high-intermediate through the SBOA. The results show that there was an improvement in the students' speaking skills after the creation of their Scribe videos and the students had positive perceptions of digital storytelling. Hence, educators could possibly use digital storytelling as a tool to expand their repertoire of teaching strategies and motivate students to speak in English.
\end{abstract}

Keywords: VideoScribe, Speaking Skill, Digital Storytelling, Suburban School, Oral Assessment

\section{Introduction}

\section{A. Background of the Study}

The extensive use of Information Communication Technologies (ICT) in the world has greatly transformed the teaching methodologies in schools from focusing on students' linguistic ability 
towards focusing on students' communicative language ability. The teaching model in Malaysia too is changing from a traditional "chalk and talk", "teacher-centered" one to a "student-centered" multi-dimensional one, which aims to develop students' speaking ability (Lu, Hou \& Huang, 2010). It covers a wide range of technologies, such as audio-visual aids, computers, mobile devices, communication devices or applications, internet as well as the various ICT services and applications. Integrating ICT in language learning allows teachers to plan and design suitable teaching method and create a learning environment for the learners, hence preparing them in a real-life application for the future (Siricord \& Yunus, 2016).

On the other hand, the teaching and learning of speaking skills are one of the biggest challenges faced by language learners and teachers, especially in second language classrooms. In an English class in the past, the teacher had to spend most of the classroom time lecturing while students would often passively receive linguistic knowledge either from the teacher or from the textbook, but their speaking ability could not be adequately trained and developed. An ICT-based software, such as VideoScribe is able to integrate all the skills especially speaking skills into the students' practice (Siricord \& Yunus, 2016). In such ICT-based language learning environments, the teaching models change accordingly.

The development of speaking skills is fundamental for English as Second Language (ESL) learners to communicate effectively. Speaking has an important role in communication (Agravat \& Raval, 2015). Without speech, communication will be merely scripted. Experts state that the ability to communicate orally or to speak is equal to knowing the given language since speaking is the main means of human communication (Afshar \& Asakereh, 2016). According to a study by Spawa \& Hassan (2013), Malaysian students believe that speaking skill is the most important skill to learn. Moreover, in this technology era, the English language is a crucial medium of communication (Afshar \& Asakereh, 2016). On the other hand, the focus on mastering and rote learning skills and applying them in examinations eventually eroded communicative competence among the students (Fauzi \& Shah, 2017).

However, not all students are able to speak English fluently upon completing secondary school. The lamentable state has been highlighted by many (Hiew, 2012; Spawa \& Hassan, 2013). The usual practice in the Malaysian English classroom is answering reading comprehension questions and essay writings with limited listening and speaking exercises (Musa, Koo \& Azman, 2012). Still, in a speaking class, there is much emphasis on producing full correct sentences and choral responses, and codemixing is evident (Lim, 2013). This dire state of affairs is also felt beyond the schooling years. According to a study conducted by Malaysia's Performance Management and Delivery Unit, there is unemployment among graduates because they cannot speak in English (Karim, 2016). Thus, with the help of interactive software such as VideoScribe, it is a great opportunity to try a different alternative to teach speaking skills to students. Hence, this study aims to investigate if digital storytelling improves students' speaking skills and the perceptions of the students with regards to the use of digital storytelling to improve their speaking skills. 


\section{Literature Review}

\section{A. Speaking}

Speaking is an important skill used to communicate thoughts and carry out transactions. However, the oral expression is a complex process that not only involves producing the right sounds in the right patterns of rhythm and intonation but also the choice of words and inflections in the right order to convey the right meaning (Mackey 1965 as cited in Bygate, 1987). Besides, spoken sentences are also shorter than written ones. Other than that, unlike writing, the words are being spoken as they are being decided and as they are being understood. Thus, mistakes may be made in the message and the wording. The speaker may also forget what was said moments ago. Speech is affected by time constraints, the lack of planning and production under pressure (Bygate, 1987).

\section{B. Difficulty in Speaking a Learned Language}

The Office for Standards in Education in its 2008 report highlighted that children studying foreign languages have poor speaking skills despite improvements in the quality of teaching and learning. Furthermore, the report found that speaking was the least developed of pupils' skills and that pupils' inability to express themselves had a negative impact on their confidence and enthusiasm (as cited in Tuttle \& Tuttle, 2012). In Malaysia, where English is the second language, the scenario is no different. In a survey conducted among 75 students in primary schools in Nilai, $44 \%$ of the students responded that speaking English in a variety of situations was difficult (Fauzi \& Shah, 2017). Compounding the problem, some learners do not use the English language at home to communicate with their family members and surprisingly, even if they are fluent in English, they use their mother tongue to express intimacy within the family (Singh, 2014).

\section{Technology to Teach Speaking}

With the myriad of web tools, software and hardware available, teachers can choose the ones that students find appealing to make a difference in their learning and prepare them for the future. As students nowadays learn a lot by self-discovering (Manty, Yunus, Badusah \& Shah, 2017), students can interact with information, create knowledge, and then communicate the results to a real audience (Soloman \& Schrum, 2010). Indeed, as averred by Guth \& Petrucco (2009), today's students need to learn how to manage the overload of information and create knowledge. Language acquisition especially is a lifelong process that cannot end with traditional education, but rather must be cultivated throughout life. In a research conducted by Early and Swanson (2008), there are numerous benefits of using digital audio recordings for speaking assessments with Japanese and Spanish undergraduates. The undergraduates were less anxious and more likely to experiment with new Second or Foreign Language structures and vocabulary while trying to imitate native speakers' speech, responded more thoroughly, and felt an increase in their sense of control of academic success (as cited in Swanson \& Schlig, 2010; Harb, Bakar \& Krish, 2013) also discovered that technology is perceived as important to improving undergraduates' oral skills.

In local research, Fauzi and Shah (2017) found out that $89 \%$ of the primary students believe that speaking would be more fun with the use of internet resources. In fact, $57 \%$ of respondents believed that technology will help improve their speaking skills and 53\% of them use internet resources to help 
them learn to speak. Meanwhile, Manty et al. (2017) investigated the use of Voki among undergraduates. By the end of the research, they were more confident to speak in English, showed positive perceptions with regards to the use of Voki in language learning and agreed that Voki application has helped them to improve their speaking skills. Mansor and Yunus (2017) studied the use of Blendspace. $60 \%$ of the undergraduates perceived the lecturer's use of Blendspace made learning English speaking skills more fun. $70 \%$ of respondents believed that Blendspace developed their English-speaking skills and $75 \%$ of them believed that Blendspace increased their selfconfidence in speaking the English language.

\section{VideoScribe}

VideoScribe is a software created by Sparkol, used for creating whiteboard animations and an engaging new form of digital storytelling which replicates 'stop-motion capture style'. Users can arrange the images, effects, audio, music, and text creatively for their presentations. The completed video can be downloaded as an $\mathrm{mp4}$, wmw, mov, avi or shared directly through YouTube, Facebook, Sho.co or an image sequence.

\section{E. Digital Storytelling}

Digital storytelling is the modern art expression of the ancient art of storytelling (Razmi, Pourali \& Nozad, 2014). Students narrate the scripts of their stories and record themselves. This material is next mixed with different types of multimedia, including computer-based graphics, computer-generated text, images, video clips, and music creating a digital story with a length of between 2 and 10 minutes so that it can be played on the computer or any other devices that can play a video. Robin (2016) delineates three different categories of digital storytelling. First, personal narratives - stories that contain excerpts from one's life. Second, historical documentaries and third, stories that serve to inform or instruct the viewers on concepts and practices.

\section{F. Digital Storytelling Aids Speaking Skills}

In recent years, researchers have been studying the use of digital storytelling to improve speaking skills among learners of English (Razmi et al., 2014; Abdolmanafi-Rokni \& Qarajeh, 2014; Dong 2015; Fitria 2017; Tunc 2017). Engin (2014) states that student-created videos promoted second language learning through research, simplification, explanation, and encouraged more focus on form (as cited in Kathalina, 2017). Consequently, students become the 'storytellers' who present the stories they have created to audiences (Kajder, 2006 as cited in Razmi et al., 2014).

Abdolmanafi-Rokni \& Qarajeh (2014) conducted a study among EFL learners at Param Noor University in Iran. The experimental group received treatment of digital storytelling and their feedback at the end of the session was remarkable. 93.4\% of the sample unanimously stated that the application of digital storytelling leads to the development of their speaking performance. Digital storytelling not only improved the speaking skills of the learners but also their motivation toward language learning in general and speaking skills in particular. 
Razmi et al. (2014) did a similar study focusing on intermediate EFL learners. One group was the control group while in the other group, learners were required to use Microsoft Powerpoint to present their stories. The researchers found a significant difference in oral performance between the two groups. Besides, findings also reveal that digital storytelling increases students' motivation, students become more interested in their learning and even take more responsibility for their learning.

Whiteboard animation tools can be used to tell a digital story (Watkins 2018). The elements in VideoScribe makes it an ideal means for digital storytelling. The strength of VideoScribe as a medium of learning skills is its' combination of text, audio, images in one online medium as it is able to provide a good stimulus to learners (Fitria, 2017). In fact, VideoScribe was used as a digital storytelling tool in a study conducted by Tunc (2017) on Digital Storytelling Activities and Assessment of Students' Views. Besides, Siricord and Yunus (2016) also found out that most learners were willing to participate actively involved in the project based learning via VideoScribe. VideoScribe actually inhibited students' fear of making errors, creating a safe platform, especially for weaker students. Besides that, learners were able to peer check and identify their friends' errors in pronunciations.

\section{Methodology}

\section{A. Research Design}

For the purpose of this study, an action research was done based on the model proposed by Kemmis and McTaggart. The four steps involved are planning, acting, observing and reflecting.

Figure $1.0 \mathrm{Kemmis}$ and McTaggart

(as cited in Altrichter, Kemmis \& McTaggart, 2007)

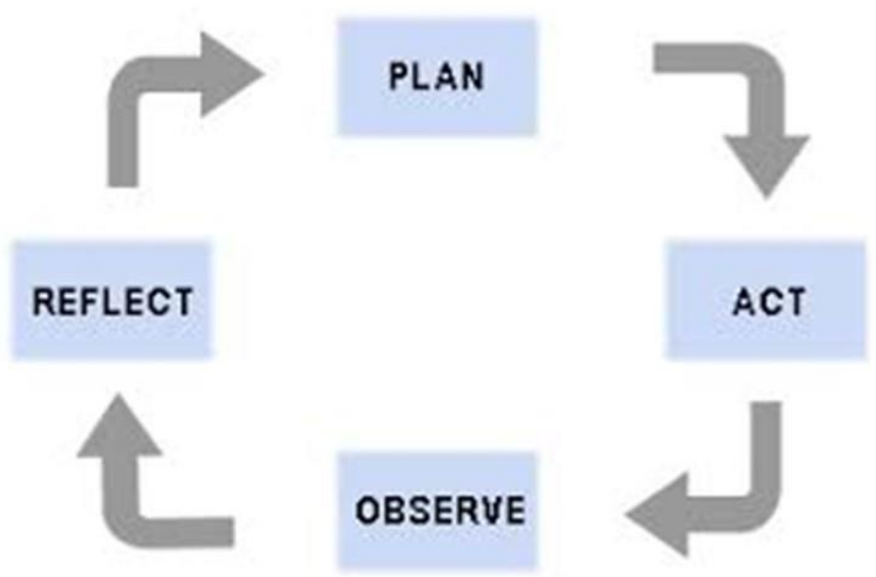




\section{1) Planning}

An intervention to solve the learning problem is planned. Subscription to VideoScribe is made, and teaching materials and tools for data collection are prepared. Interview questions are also written prior to the posttest.

\section{2) Acting}

The plan is being implemented where the students familiarize themselves with producing videos using VideoScribe with the guidance of the researcher. The students are assigned to create 2 Scribe videos with multimedia after writing 2 personal narratives about their family and friends.

\section{3) Observing}

The test using the SBOA instrument is carried out to observe the difference in speaking skills before and after creating 2 Scribe videos. An interview between the researcher and participants is done to know the participants' perceptions of using VideoScribe to enhance their speaking skills.

\section{d) Reflecting}

To discuss the result of students, the SBOA scoresheet is analyzed to determine if the treatments make a difference in their speaking abilities.

\section{B. Participants}

Convenience sampling was used. The sample consisted of 20 Form 4 students were selected from a suburban secondary school in Pahang. 12 boys and 8 girls were the participants. Their language proficiency was rated as high-intermediate through the School Based Oral Assessment (SBOA).

\section{Instrument}

For this research, the researchers employed quantitative data gathering technique. The School Based Oral Assessment (SBOA) form was the main instrument used as it is a valid and reliable tool to assess oral proficiency among upper public secondary school students. It has 5 constructs and each construct carries a maximum mark of 6 .

\section{Procedures}

This study was conducted at a suburban school in Pahang over a period of five weeks. In order to have participants with the same level of proficiency, a pre-test was conducted using the School Based Oral Assessment (SBOA) rubrics. 20 students were randomly selected and identified to be participants of this study. The students stayed back twice a week and each session lasted for 60 minutes. In this study, the researchers introduced the concept of digital storytelling and demonstrated the use of VideoScribe to the students. All the students were to create two Scribe videos complete with text, visuals, and audio recordings within the span of 4 weeks. In the first week, each student had to write an essay about his or her family. The participants were also taught how to create Scribe videos. The second week saw students recording the narration of their essays and creating Scribe videos. In the two following weeks, this process was repeated with students writing 
about their friends. The main aim was to encourage students to narrate stories that were personal to them. In the fifth week, students had to sit for a post-test and assessed again with the SBOA rubrics to measure progress.

Figure 2.0 Timeline of Study

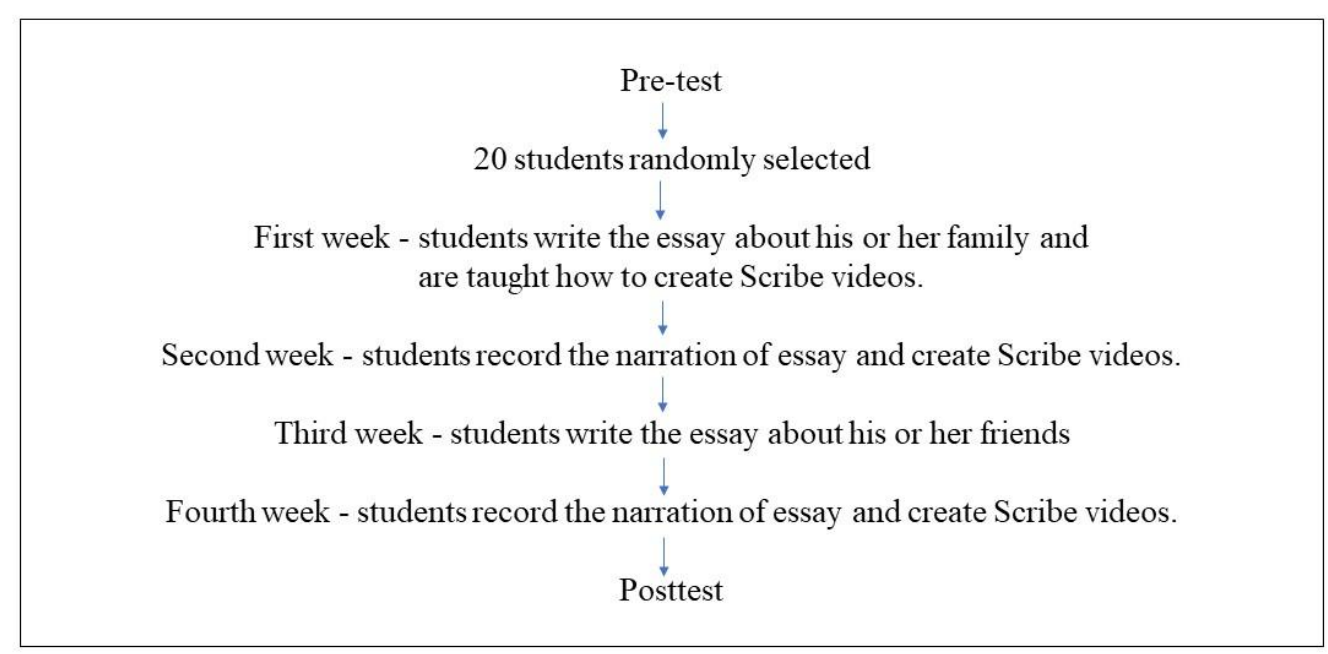

\section{E. Data Analysis}

\section{1) Quantitative Data Analysis}

Upon completion of the posttest, the SPSS software was used to compare the means of the pretest and posttest. A normality test prior to the paired t-test was run to compare both data based on their SBOA scores.

2) Qualitative Data Analysis

An interview was carried out to gather the participants' perceptions of the use of digital storytelling to improve their speaking skills.

\section{Results and Discussion}

\section{A. Sample Characteristics}

A Shapiro-Wilk's test ( $p>0.05$ ) as prescribed by Razali \& Wah (2011) was conducted and a visual inspection of their histograms, normal Q-Q plots and box plots showed that the data is little skewed and kurtotic but it does not differ significantly from normality, with a skewness of 0.606 (SE $=0.512$ ) and a kurtosis of 0.239 (SE $=0.992$ ). Thus, it can be assumed the data is normally distributed in terms of skewness and kurtosis.

\section{B. Pre-test and Posttest}

The aim of the action research was to investigate if digital storytelling improves students' speaking skills. A paired sample t-test was used to compare the results of the pretest and posttest. 
Research question 1: Does digital storytelling improve students' speaking skills?

Table 1 below shows the summary of the pretest and posttest. The minimum score in the pretest is 18 and the maximum score is 25 . As for the posttest, the minimum score is 20 and the maximum score is 26 . The margin of difference between the pretest and posttest range from 0 to 3 which is considered an improvement, albeit a small one.

Table 1: Summary of the Pretest and Posttest Scores

\begin{tabular}{|l|l|c|c|c|}
\hline No & Participants & Pretest marks & Posttest marks & Margin of Difference \\
\hline 1. & Participant 1 & 20 & 21 & 1 \\
\hline 2. & Participant 2 & 21 & 23 & 2 \\
\hline 3. & Participant 3 & 22 & 24 & 2 \\
\hline 4. & Participant 4 & 21 & 22 & 1 \\
\hline 5. & Participant 5 & 22 & 23 & 1 \\
\hline 6. & Participant 6 & 24 & 24 & 0 \\
\hline 7. & Participant 7 & 23 & 24 & 1 \\
\hline 8. & Participant 8 & 23 & 24 & 1 \\
\hline 9. & Participant 9 & 24 & 24 & 0 \\
\hline 10. & Participant 10 & 25 & 26 & 1 \\
\hline 11. & Participant 11 & 24 & 25 & 1 \\
\hline 12. & Participant 12 & 22 & 24 & 2 \\
\hline 13. & Participant 13 & 24 & 25 & 1 \\
\hline 14. & Participant 14 & 18 & 21 & 3 \\
\hline 15. & Participant 15 & 22 & 24 & 2 \\
\hline 16. & Participant 16 & 20 & 21 & 1 \\
\hline 17. & Participant 17 & 22 & 22 & 0 \\
\hline 18. & Participant 18 & 21 & 22 & 0 \\
\hline 19. & Participant 19 & 19 & 20 & 1 \\
\hline 20. & Participant 20 & 23 & 26 & 3 \\
\hline & Minimum Score & 18 & 20 & \\
\hline & Maximum Score & 25 & 26 & \\
\hline
\end{tabular}

A paired sample t-test was run with the following hypotheses:

Ho: There is no significant difference in the results of students who were given digital storytelling treatments.

Ha: There is a significant difference in the results of students who were given digital storytelling treatments.

Table 2 shows the mean for the pretest and posttest. The group obtained a mean value of 21.95 in the pre-test and 23.25 in the post-test. This shows that the students did better in the posttest. 
Table 2: Paired Sample Statistics

\begin{tabular}{|l|l|l|l|l|}
\hline & Mean & $\mathbf{N}$ & $\begin{array}{l}\text { Std. } \\
\text { Deviation }\end{array}$ & $\begin{array}{l}\text { Std. } \\
\text { Error } \\
\text { Mean }\end{array}$ \\
\hline Pair 1 & & & & \\
Posttest & 23.25 & 20 & 1.713 & .383 \\
Pre-test & 21.95 & 20 & 1.959 & .438 \\
\hline
\end{tabular}

Table 3 shows the results of the paired t-test which was used to compare the means of the sample in the pretest and posttest. As the results in Table 3 indicate, the $t$ value is 5.940 and the sig=0.000 which is less than 0.05 . Since $p<0.05$, the null hypothesis is rejected hence, there is a significant difference in the results of students who were given digital storytelling treatments. It clearly indicates that there is an increase in the students' speaking skills. This finding concurs with past studies on digital storytelling enhancing speaking skills (Razmi et al., 2014; Abdolmanafi-Rokni \& Qarajeh, 2014; Rahimi \& Yadollahi, 2017). Hence, it can be deduced that digital storytelling benefitted the students.

Table 3: Paired Samples Test

\begin{tabular}{|l|l|l|l|l|l|l|l|}
\hline \multirow{2}{*}{} & & \multicolumn{3}{|l|}{ Paired Differences } & t & df & $\begin{array}{l}\text { Sig. (2- } \\
\text { tailed) }\end{array}$ \\
\cline { 3 - 8 } & & Mean & $\begin{array}{l}\text { Std. } \\
\text { Deviation }\end{array}$ & $\begin{array}{l}\text { Std. } \\
\text { Error } \\
\text { Mean }\end{array}$ & & & \\
\hline \multirow{2}{*}{ Pair 1 } & Posttest & 1.300 & .979 & .219 & 5.940 & 19 & .000 \\
\cline { 2 - 7 } & Pre-test & & & & & \\
\hline
\end{tabular}

Research Question 2: What are the perceptions of the students with regards to the use of digital storytelling to improve their speaking skills?

Based on the interview conducted, most of the participants believed that digital storytelling was a useful means to improve their speaking. The following are some of their comments:

"I feel more confident to speak in English now because my friends are not listening and laughing at me when I make mistakes while speaking. I feel free to do the recording."

"At first it was difficult to create a video, but after the guidance from my friends and teacher, it is much easier than I thought. Now, I can create a video in English to present my stories and ideas."

"Videoscribe is a new application to me. I like it better than other applications as it has voiceover and I can listen to my voice again and again while I am doing my video. It makes me conscious of not making the mistakes especially in pronunciation that I did in my recording." 
"I like Videoscribe because I can show my talent in making videos in English. I have never tried one in English before. So, this experience is great. I am waiting to do another video."

"It is fun to watch my friends' shared videos and I learn a lot. I can listen to their voices and get to know their families and friends via their videos. I can leave comments too."

"At first it was difficult to create a video, but after the guidance from my friends and teacher, it is much easier than I thought. Now, I can create a video in English to present my stories and ideas."

In a nutshell, digital storytelling is viewed positively by students as a means to help improve their speaking skills. It is similar to the findings of Abdolmanafi-Rokni \& Qarajeh (2014) who found in his study $93.4 \%$ of his respondents unanimously stated that the application of digital storytelling leads to the development of their speaking performance.

Students were eager to speak up because they each had stories to share. As it taps into the students' personal experiences, digital storytelling empowers each student to be a storyteller and this motivates them to develop their oral abilities (Lu et al., 2010).

Furthermore, digital storytelling gave them the freedom to express themselves with multimedia. More importantly, the use of digital storytelling is beneficial in teaching students speaking skills. It motivates them to self-check and correct themselves in order to speak fluently without any hesitance. A parallel finding was discovered by Musa et. al (2012) who aver that by using technology to learn speaking skills, respondents are more productive, expressive and express their ideas more creatively through technological tool assistance.

\section{Conclusion}

Findings of this study reveal that digital storytelling improves the speaking skills of most participants. Furthermore, the participants were receptive to the idea of digital storytelling as a medium to enhance their speaking skills. Digital storytelling arouses the interest of students, and enables students to get better at speaking while becoming active learners themselves. In Malaysia, there is limited study on the use of digital storytelling in the English language classroom. With more schools being equipped with computers and internet access, digital storytelling is an inexpensive and viable method to improve suburban students' speaking skills. Various web tools should be looked into so that students can benefit from them. Lastly, since there were only 20 participants altogether, the results of this research cannot be generalized and merely show the effect of the study on the students of this particular school. Further research should be carried out on students of intermediate or lower proficiency levels.

\section{References}

Abdolmanafi-Rokni, S. J. \& Qarajeh, M. (2014). Digital Storytelling in EFL classrooms: The effect on the oral performance. International Journal of Language and Linguistics, 2(4), 252-257. 
Afshar, H. S. \& Asakereh, A. (2016). Speaking Skills Problems Encountered by Iranian EFL Freshmen and Seniors from Their Own and Their English Instructors' Perspectives. Electronic Journal of Foreign Language Teaching, 13(1), 112-130.

Agravat, M. R., \& Raval, T. C. (2015). Using Web 2.0 Tools 'Voki' \& 'Voxopop' for Enhancing the Speaking Skills. Journal of Technology for ELT, 4(2), 1-3.

Altrichter, H., Kemmis, S., \& Mac Targgart, R, (2007). The Concept of Action Research. The Learning Organization, 9(3), 125-135.

Bygate, M. (1987). Speaking. Oxford: Oxford University Press.

Dong, Y. (2015). Using digital storytelling to support EFL learning in China (Master's thesis). Retrieved from http://dspace.library.uvic.ca/handle/1828/6035

Fauzi, N. E. M. \& Shah, P. M. (2017). Practices and Benefits in Learning Speaking In English Through Technology: A Survey of Primary Schools in Nilai. Prosiding Seminar Pendidikan Serantau KeVIII 2017, $67-74$.

Fitria, I. (2017). Pengaruh Media Pembelajaran VideoScribe Terhadap Perkembangan Bahasa Anak Usia Dini Di Taman Kanak-kanak Islam Bina Balita Bandar Lampung. [The Influences of VideoScribe on the Development of Children's Language at the Islamic Kindergarten of Bina Balita Lampung City] (Master's thesis). Retrieved from http://repository.radenintan.ac.id/2653/

Guth, S., \& Petrucco, C. (2009). Social Software and Language Acquisition. In Marriott, R. C. V. \& Torres, P. L. (Eds.), Handbook of Research on E-Learning Methodologies For Language Acquisition (pp. 424 - 442). Hershey PA: Information Science Reference.

Harb, J., Bakar, N. A. \& Krish, P. (2013). Instructors' and Students' Perceptions Towards Using Technology in Teaching and Learning Listening and Speaking at Jordanian Universities. Interdisciplinary Journal of Contemporary Research in Business January 2013, 4(9), 1027 - 1041.

Hiew, W. (2012). English Language Teaching and Learning Issues in Malaysia: Learners' Perceptions via Facebook Dialogue Journal. International Refereed Research Journal, 3(1), 11-19.

Karim, H. A. (2016, February 3). Unemployed because they can't speak English. New Straits Times. Retrieved from https://www.nst.com.my/news/2016/02/125529/unemployed-because-they-cantspeak-english

Kathalina, C. (2017). The use of Powtoons and VideoScribe in a flipped classroom to improve listening and speaking skills on distance undergraduate students (Master's thesis). Retrieved from http://dspace.utpl.edu.ec/bitstream/20.500.11962/20882/1/MorochoCristina.pdf

Lim, T.D. (2013). Analysing Malaysian English Classrooms: Reading, Writing, Speaking and Listening Teaching Strategies (Doctoral dissertation). Retrieved from https://digital.lib.washington.edu/researchworks/handle/1773/25020

Lu, Z., Hou, L., \& Huang, X. (2010). A Research on a Student-Centred Teaching Model in an ICTbased English audio-video Speaking Class. International Journal of Education and Development, 6(3), 101-123.

Mansor, N. \& Yunus, M. M. (2017). The Use of Blendspace to Improve Students' English Speaking Skills. Prosiding Seminar Pendidikan Serantau Ke-VIII 2017, 67 - 74.

Manty, M., Yunus, M. M., Badusah, J. \& Shah, P. M. (2017). Using Voki to Enhance Speaking Skills. Prosiding Seminar Pendidikan Transdisiplin. (STEd 2017), 668-672. 
Musa, N. C., Koo, Y. L. \& Azman, H. (2012). Exploring English Language Learning and Teaching in Malaysia. GEMA Online ${ }^{\circledR}$ Journal of Language Studies, 12(1), 35-51.

Rahimi, M., \& Yadollahi, S. (2017). Effects of offline vs. online digital storytelling on the development of EFL learners' literacy skills. Cogent Education, 4(1), 1-13.

Razali, N. M. \& Wah, Y. B. (2011). Power Comparisons of Shapiro Wilk, Kologorov-Smirnov, Lilliefors and Anderson-Darling Tests. Journal of Statistical Modelling and Analytics, 2(1), 21-33.

Razmi, M., Pourali, S. \& Nozad, S. (2014). Digital Storytelling in EFL Classroom (Oral Presentation of the Story): A Pathway to Improve Oral Production. Procedia-Social and Behavioral Sciences, 98, 1541-1544.

Robin, B. R. (2016). The Power of Digital Storytelling to Support Teaching and Learning. Digital Education Review, 30, 17-29.

Singh, H. K. S. (2014). Attitudes Towards English Language Learning and Language Use Among Secondary School Students (Master's thesis). Retrieved from http://studentsrepo.um.edu.my/5686/1/PART_2 \%26 3 RESEARCH REPORT_(no. 3)_[FULL_EDITED]_(1).pdf

SiRicord, T. S., \& Yunus, M. M. (2016). Learners' perceptions on the effectiveness of VideoScribe on improving listening and speaking in rural school of Sarawak. Asian EFL Journal, 6, 50-61.

Soloman, G., \& Schrum, L. (2010). Web 2.0 How-to for Educators. United States of America: International Society for Technology in Education.

Spawa, C. M. C., \& Hassan, F. (2013). "I don't know English": Beliefs and Practices in the Teaching of Speaking in the ESL Classroom. Pertanika Journal of Social Sciences \& Humanities, 21(2), 449-460.

Swanson, P. B., \& Schlig, C. (2010). Improving second language speaking proficiency via interactional feedback. International Journal of Adult Vocational Education and Technology (IJAVET), 1(4), 17-30.

Tunc, O.A. (2017). Material Development Based on Digital Storytelling Activities and Assessment of Students' Views. International Journal of Evaluation and Research in Education (IJERE), 6(1), 54-63.

Tuttle, H.G., \& Tuttle, A. (2012). Improving Foreign Language Speaking Through Formative Assessment. New York: Eye On Education.

Watkins, D. (2018). Bring E-Learning to Life. TD, May, 69-72. 